\title{
Stepwise Introduction of Flexibility into Aromatic Dicarboxylates Forming \\ Uranyl Ion Coordination Polymers: a Comparison of
}

2-Carboxyphenylacetate and 1,2-Phenylenediacetate

\author{
Dr. Pierre Thuéry*[a] and Dr. Jack Harrowfield*[b] \\ [a] Université Paris-Saclay, CEA, CNRS, NIMBE, 91191 Gif-sur-Yvette, France \\ E-mail: pierre.thuery@cea.fr, http://iramis.cea.fr/nimbe/ \\ ${ }^{[b]}$ ISIS, Université de Strasbourg, 8 allée Gaspard Monge, 67083 Strasbourg, France \\ E-mail: harrowfield@unistra.fr, https://isis.unistra.fr/fr/
}

Keywords: Uranyl cation / Carboxylic acids / Dicarboxylatye ligands / Structure elucidation

\begin{abstract}
2-Carboxyphenylacetate $\left(\mathrm{cpa}^{2-}\right)$ and 1,2-phenylenediacetate $\left(1,2-\mathrm{pda}^{2-}\right)$ have been reacted with uranyl cations under solvo-hydrothermal conditions to generate six homo- or heterometallic complexes. Both [UO ${ }_{2}$ (cpa)] (1) and $\left[\mathrm{UO}_{2}(\mathrm{cpa})(\mathrm{phen})\right]$ (2), where phen is 1,10-phenanthroline, crystallize as monoperiodic coordination polymers. [ $\left.\mathrm{Ni}(\text { bipy })_{3}\right]\left[\left(\mathrm{UO}_{2}\right)_{2}(\mathrm{cpa})_{3}\right] \cdot 2.5 \mathrm{H}_{2} \mathrm{O}$ (3), is a diperiodic network with the hcb topology, in which the hexagonal cells distort to accommodate the counterions. [ $\left.\mathrm{UO}_{2}(\mathrm{cpa})_{2} \mathrm{Ni}\left(R, S-\mathrm{Me}_{6} \mathrm{cyclam}\right)\right](4)$ crystallizes as a heterometallic diperiodic network, in which uranyl dicarboxylate chains are assembled by bridging $\mathrm{Ni}^{\prime \prime}$ cations. While [dmaepH $\left.\mathrm{d}_{2}\right]\left[\left(\mathrm{UO}_{2}\right)_{2}(1,2-\mathrm{pda})_{3}\right] \cdot 3 \mathrm{H}_{2} \mathrm{O}$ (5), where dmaep is 1,4-bis(2'-dimethylaminoethyl)piperazine, is a diperiodic hcb network, $[\mathrm{QH}]_{2}\left[\left(\mathrm{UO}_{2}\right)_{2}(1,2-\mathrm{pda})_{3}\right] \cdot 3 \mathrm{CH}_{3} \mathrm{CN}(6)$, where $\mathrm{Q}$ is quinuclidine, is the first example of a triperiodic framework in the uranyl-phenylenediacetate family, its topological type being bto. The complex involving the related ligand 1,4-phenylenediacetate $\left(1,4-\mathrm{pda}^{2-}\right),[\mathrm{QH}]_{2}\left[\left(\mathrm{UO}_{2}\right)_{2}(1,4-\mathrm{pda})_{3}\right] \cdot 2 \mathrm{CH}_{3} \mathrm{CN}(7)$, is a daisychain-like monoperiodic polymer. These and previously reported results are discussed in terms of ligand flexibility and ability to form large chelate rings.
\end{abstract}




\section{Introduction}

Polycarboxylates are ligands among the most used for the synthesis of uranyl ion-containing coordination polymers and frameworks, ${ }^{[1-5]}$ and, considering the huge range of geometries and denticities covered by these anions, this allows for detailed studies of the effect of fine modifications of the ligands upon the structure of the complexes formed. In particular, comparison of the structures of uranyl ion complexes of homologous pairs of ligands such as adamantane-dicarboxylate and -diacetate, $^{[6-9]}$ or phthalate ${ }^{[10]}$ and 1,2phenylenediacetate ${ }^{[11-13]}$ has enabled some assessment of the influence of rotation about additional $\mathrm{C}-\mathrm{C}$ single bonds to be made. In these particular cases, however, the influence is that of the addition of two such bonds and comparisons involving the singly modified ligands 3-carboxylato-adamantane-1-acetate or 2-carboxyphenylacetate are lacking. For the former, its chirality introduces a further complication so that the latter, even though it may adopt chiral conformations, is the simpler system for initial investigation. The present report concerns the crystal structures of four uranyl ion complexes of 2-carboxyphenylacetate $\left(\mathrm{cpa}^{2-}\right)$ and two new complexes of $1,2-$ phenylenediacetate $\left(1,2-\mathrm{pda}^{2-}\right)$ to be placed within the context of their known relatives, as well as a new complex of 1,4-phenylenediacetate $\left(1,4-\mathrm{pda}^{2-}\right)$ for purpose of comparison with 1,2-pda ${ }^{2-}$. These complexes have been synthesized under solvo-hydrothermal conditions, in the presence of different possible additional ligands or counterions. The counterions used have been either the bulky, metalcontaining $\left[\mathrm{Ni}(\text { bipy })_{3}\right]^{2+}$ (bipy $=2,2^{\prime}$-bipyridine $)$ and $\left[\mathrm{Ni}\left(R, S-\mathrm{Me}_{6} \mathrm{Cyclam}\right)\right]^{2+}\left(R, S-\mathrm{Me}_{6} \mathrm{Cyclam}\right.$ (meso isomer) $=7(R), 14(S)-5,5,7,12,12,14$-hexamethyl-1,4,8,11-tetraazacyclotetradecane), or protonated quinuclidine $\left(\mathrm{HQ}^{+}\right)$. An attempt to use protonated Me $\mathrm{M}_{6}$ trien $(1,1,4,7,10,10-$ hexamethyltriethylenetetramine) as a counterion resulted in an in situ transformation of the latter into 1,4-bis(2'-dimethylaminoethyl)piperazine (dmaep). A search of the Cambridge 
Structural Database (CSD, version $5.41^{[14]}$ ) shows that, although 2-carboxyphenylacetate is a common ligand for d-block metal cations and has also been used with lanthanide cations, no structure with an actinide cation has been reported previous to the present examples.

\section{Results and Discussion}

\section{Syntheses}

Crystals of all complexes were grown under solvo-hydrothermal conditions at a temperature of $140{ }^{\circ} \mathrm{C}$, the crystals being formed directly from the pressurized and heated reaction mixtures and not as a result of subsequent cooling. The organic cosolvents used were either acetonitrile (1, 6 and 7), N,N-dimethylformamide (DMF) (3-5), or tetrahydrofuran (THF) (2), but only in $\mathbf{6}$ and $\mathbf{7}$ are solvent (acetonitrile) molecules retained in the final compound. The most unexpected observation here is that of the reaction affecting protonated $\mathrm{Me}_{6}$ trien in the synthesis of complex $\mathbf{5}$. As indicated in Scheme 1, under the conditions used, this molecule underwent a transalkylation reaction giving a central piperazine ring, similarly to

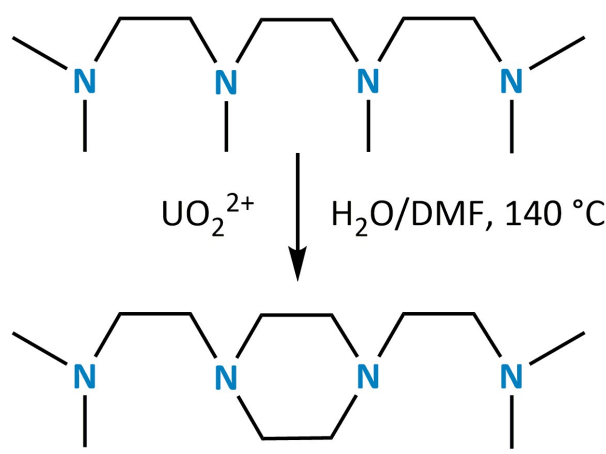

Scheme 1. Transalkylation of Mestrien during the synthesis of complex 5. Protonation of the amine groups is not indicated.

the known reaction of $N, N, N^{\prime}, N^{\prime}$-tetramethylethylenediamine, ${ }^{[15]}$ the lateral amine groups being untouched. It may be possible that uranyl cations act as catalysts for this reaction, this 
being one more example of the occurrence of unexpected organic reactions when using metal cations under solvo-hydrothermal conditions requiring prolonged heating. It is known that, when photo-excited, uranyl is able to abstract a hydrogen atom to form an organic radical, ${ }^{[16]}$ and this may be the mechanism at play here. Except for compound 1, for which the metal/dicarboxylate ligand stoichiometry is $1: 1$ in both the solution and the isolated complex, the 7:10 stoichiometry has been chosen for all syntheses in order to favor the formation of an anionic uranium polycarboxylate species and consequent inclusion of counterions, which indeed occurs in all cases but $\mathbf{2}$, for which the $\mathrm{Pb}^{\text {"l }}$ cations present are not included in the complex, the 1,10-phenanthroline (phen) coligand being bound to uranyl. The stoichiometry in the solid state is generally 2:3 as expected, except for complexes $\mathbf{2}$ and 4 in which it is $1: 1$ and $1: 2$, respectively.

\section{Crystal Structures}

The complex $\left[\mathrm{UO}_{2}(\mathrm{cpa})\right](1)$, shown in Figure 1, is the simplest species obtainable with this ligand. The carboxylate substituent of the $\mathrm{cpa}^{2-}$ anion bridges two cations in the syn/anti $\mu_{2^{-}}$ $\kappa^{1} O: \kappa^{1} O^{\prime}$ mode, while the acetate group is both chelating and bridging in the $\mu_{2}-\kappa^{2} O, O^{\prime}: \kappa^{1} O$ mode. One metal cation being common to both groups, an eight-membered chelate ring is formed, analogous to the seven-membered rings frequent in uranyl phthalate complexes. ${ }^{[10]}$ The uranyl cation is bound to three $\mathrm{cpa}^{2-}$ ligands, two of them chelating, the uranium coordination environment being thus pentagonal-bipyramidal [U-O(oxo), 1.7611(15) and

1.7663(15) $\AA$; U-O(carboxylato), 2.4854(15) and 2.4956(15) $\AA$ for the $\kappa^{2} O, O^{\prime}$-chelating group, 


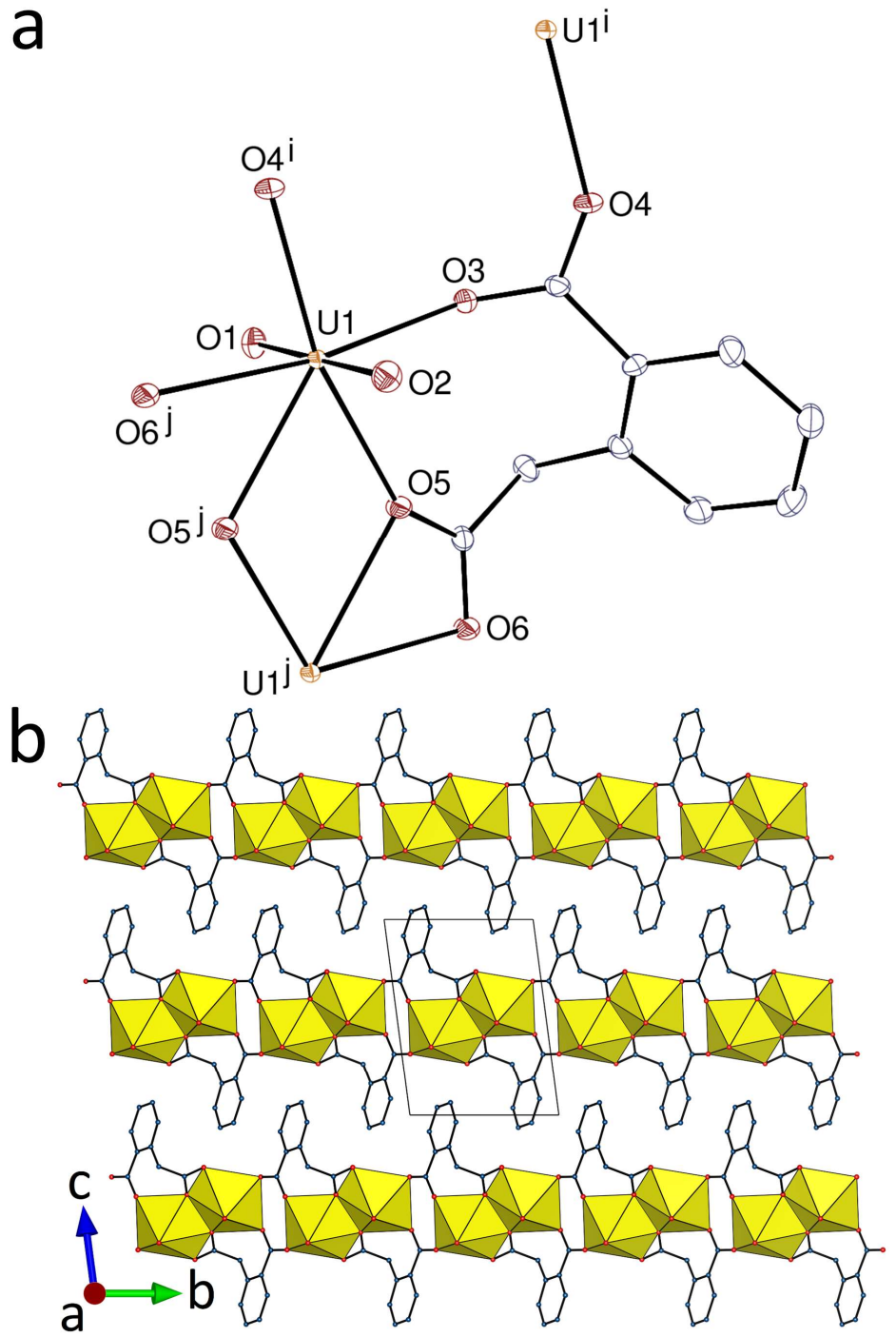

Figure 1. (a) View of complex 1. Displacement ellipsoids are drawn at the $50 \%$ probability level. Symmetry codes: $\mathrm{i}=2-x, 2-y, 1-z ; \mathrm{j}=1-x, 1-y, 1-z$. (b) View of the packing with uranium coordination polyhedra colored yellow. Hydrogen atoms are omitted in both views.

and 2.2965(15)-2.4048(15) $\AA$ for the others]. The coordination polymer formed is monoperiodic and parallel to [110], and it contains centrosymmetric, dimeric units of edgesharing uranium coordination polyhedra. While unsolvated forms of the neutral complexes containing phthalate $\left(\mathrm{pht}^{2-}\right)$ or 1,2-pda ${ }^{2-}$ have not been structurally characterized, at least in the complex $\left[\mathrm{UO}_{2}(1,2-\mathrm{pda})\right] \cdot \mathrm{CH}_{3} \mathrm{CN}^{,[13]}$ unlike $\left[\mathrm{UO}_{2}(\mathrm{pht})\left(\mathrm{H}_{2} \mathrm{O}\right)\right] \cdot \mathrm{H}_{2} \mathrm{O},{ }^{[17]}$ the solvent molecule is not coordinated. The 1,2-pda ${ }^{2-}$ complex is a diperiodic polymer in which the ligand acts as a 
bis $\left(\kappa^{2} O, O^{\prime}\right)$ bridging unit only and although the $\mathrm{pht}^{2-}$ complex is a monoperiodic (but double stranded) polymer, the carboxylate groups are involved in seven-membered chelate ring formation along with $\mu_{2}-\kappa^{1} O: \kappa^{1} O^{\prime}$ bridging. In neither case is there formation of a fourmembered $\kappa^{2} O, O^{\prime}$ chelate ring, even though such rings are seen in other uranyl ion complexes of both ligands. ${ }^{[10-13,18]}$ The chains in $\mathbf{1}$ are arranged in layers parallel to (001), which are interdigitated and tightly packed, with a Kitaigorodski packing index (KPI, calculated with PLATON ${ }^{[19]}$ ) of 0.74 . Analysis of short contacts with PLATON indicates that interlayer parallel-displaced $\pi$-stacking interactions may be present [centroid $\cdots$ centroid distance, 3.8326(14) ̊̊; dihedral angle, $0^{\circ}$; slippage, $1.31 \AA$ ]. Examination of the Hirshfeld surface $(\mathrm{HS})^{[20]}$ calculated with CrystalExplorer (ver. 3.1 ${ }^{[21]}$ indicates that these interactions are complemented by $\mathrm{CH} \cdots \mathrm{O}$ hydrogen bonds, ${ }^{[22,23]}$ as is usual in such carboxylate complexes.

In contrast to $\mathbf{1},\left[\mathrm{UO}_{2}(\mathrm{cpa})\left(\right.\right.$ phen)] (2) shows a strong resemblance to its $1,2-$ pda $^{2-}$ analogues with both phen and bipy as coligands ${ }^{[12]}$ in that $\mathrm{cpa}^{2-}$ is bound in a $\operatorname{bis}\left(\kappa^{2} O, O^{\prime}\right)$ bridging manner in a monoperiodic polymer (Figure 2). The uranium atom is chelated by two $\mathrm{cpa}^{2-}$ ligands and one phen molecule and its environment is hexagonal-bipyramidal [U-

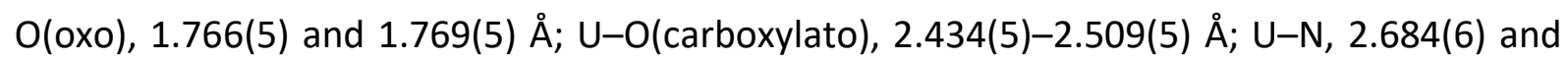
2.687(6) $\AA$ ] . As usual, the phen molecule is tilted with respect to the uranyl equatorial plane. ${ }^{[24]}$ This bis $\left(\kappa^{2} O, O^{\prime}\right)$ mode of ligand binding is almost unknown (see ahead) in phthalate $\left(\mathrm{pht}^{2-}\right)$ complexes, seemingly because formation of a seven-membered chelate ring is more favoured generally, although the exact compositional analogue of $\mathbf{1}$ is yet to be structurally 

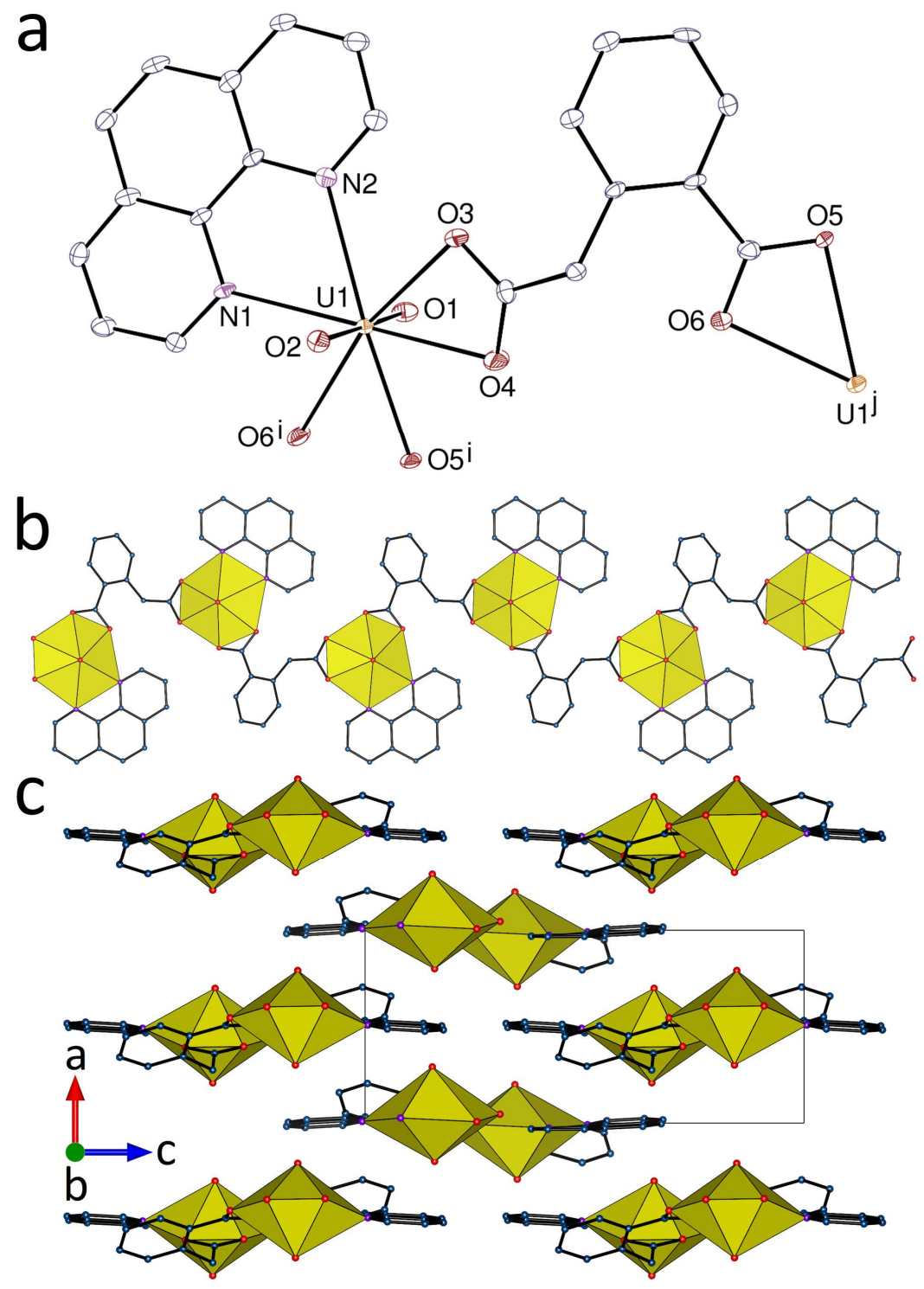

Figure 2. (a) View of complex 2. Displacement ellipsoids are drawn at the $50 \%$ probability level. Symmetry codes: $\mathrm{i}=1-x, y-1 / 2,3 / 2-z ; \mathrm{j}=1-x, y+1 / 2,3 / 2-z$. (b) View of the monoperiodic coordination polymer. (c) View of the packing. Hydrogen atoms are omitted in all views.

characterized, and in the nanotubular complex $\left[\mathrm{UO}_{2}(\mathrm{pht})\left(\mathrm{H}_{2} \mathrm{O}\right)\right] \cdot 0.32 \mathrm{H}_{2} \mathrm{O},{ }^{[18]} \mathrm{pht}^{2-}$ binds in a $\operatorname{bis}\left(\mu_{2}-\kappa^{1} O: \kappa^{1} O^{\prime}\right)$ manner. In the complex of the aliphatic analogue of phthalate, maleate $\left(\mathrm{mal}^{2-}\right),\left(\mathrm{NH}_{4}\right)_{2}\left[\mathrm{UO}_{2}(\mathrm{mal})_{2}\right]{ }^{[25]}$ the bis $\left(\kappa^{2} \mathrm{O}, \mathrm{O}^{\prime}\right)$ bridging mode is found, so it is perhaps premature to conclude that it must necessarily be rare in uranyl phthalate species. The monoperiodic assembly in $\mathbf{2}$ assumes the shape of a flat ribbon directed along [010], these 
chains being further arranged in layers parallel to (100). The calculation of short contacts indicates that several parallel-displaced $\pi$-stacking interactions involving phen aromatic rings are possibly present [centroid …centroid distances, 3.652(4)-3.854(4) $\AA$; dihedral angles, 3.0(4)-5.4(4) ${ }^{\circ}$; slippages, $\left.1.05-1.41 \AA ̊\right]$, resulting in a compact packing (KPI, 0.73).

Complex 3, $\left[\mathrm{Ni}(\text { bipy })_{3}\right]\left[\left(\mathrm{UO}_{2}\right)_{2}(\mathrm{cpa})_{3}\right] \cdot 2.5 \mathrm{H}_{2} \mathrm{O}$, provides a second example of $\mathrm{cpa}^{2-}$ binding in a bis $\left(\kappa^{2} O, O^{\prime}\right)$ bridging mode (Figure 3). Both independent uranyl cations are trischelated, with the uranium atom in a hexagonal-bipyramidal environment [U-O(oxo),

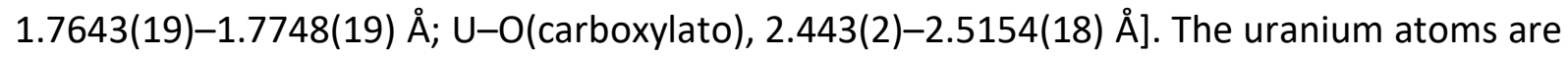
thus three-coordinated $(3-c)$ nodes and the $\mathrm{cpa}^{2-}$ ligands are simple links in the diperiodic coordination polymer formed, which is parallel to (010) and has the $\left\{6^{3}\right\}$ vertex symbol and

a
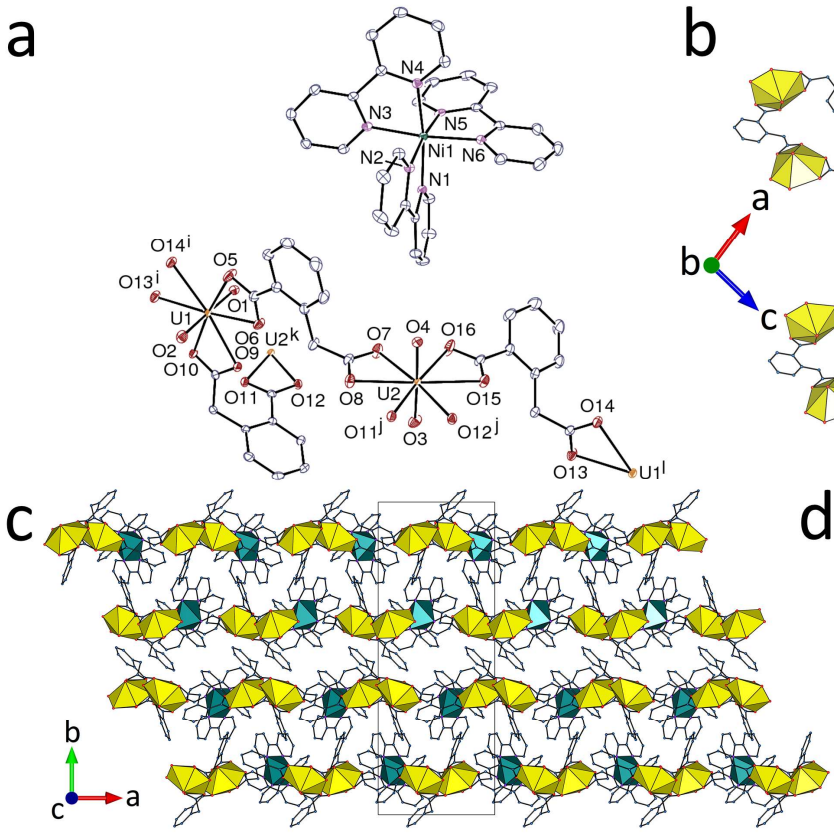
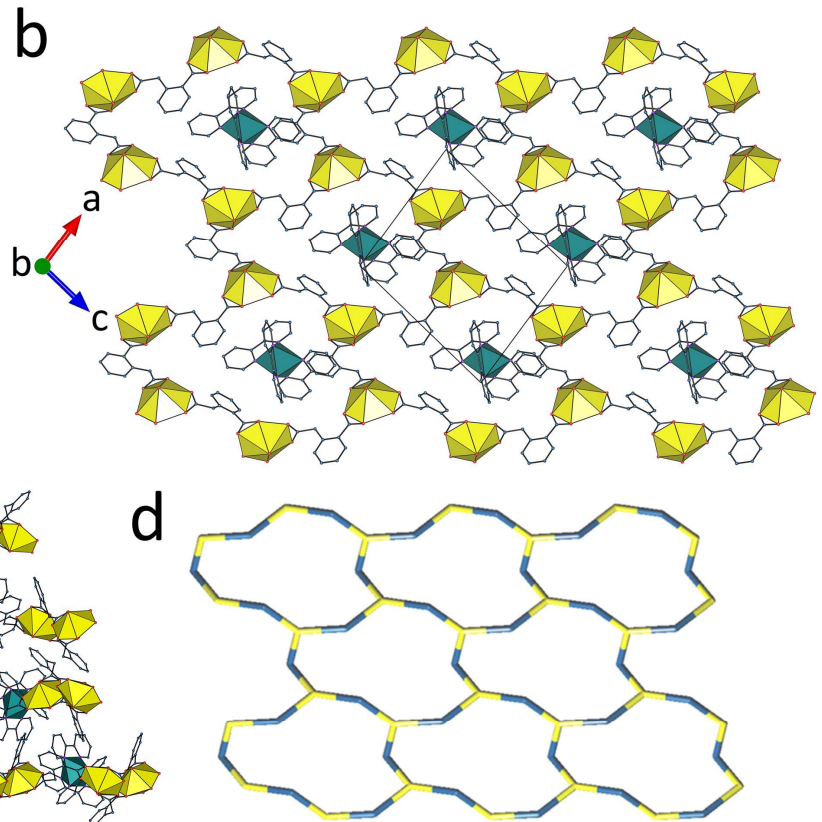

Figure 3. (a) View of complex 3 with displacement ellipsoids drawn at the $50 \%$ probability level. Solvent molecules and hydrogen atoms are omitted. Symmetry codes: $\mathrm{i}=x+1, y, z+1 ; \mathrm{j}=x-1, y, z ; \mathrm{k}=x+1, y, z ; \mathrm{I}=x$ $-1, y, z-1$. (b) View of the diperiodic coordination polymer and the counterions with uranium coordination polyhedra yellow and those of nickel green. (c) Packing with layers viewed edge-on. (d) Nodal representation of the network (yellow, uranium nodes; blue, dicarboxylate links; same orientation as in (b)). 
the hcb topological type. The cells in the network are much distorted with respect to the ideal hexagon, presumably due to inclusion of part of the counterion, which results in a compact packing (KPI, 0.69). The two possible parallel-displaced $\pi$-stacking interactions are between $\mathrm{cpa}^{2-}$ and bipy, the counterion interacting only with the polymer sheet in which it is

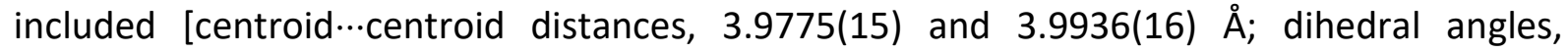
6.56(12) and $15.65(13)^{\circ}$; slippages, 1.68 and $1.53 \AA$ ]. Only one $\mathrm{CH} \cdots \pi$ interaction possibly links one $\mathrm{cpa}^{2-}$ ligand to a counterion associated to a neighbouring sheet $[\mathrm{H} \cdots$ centroid distance, $2.84 \AA$; $\mathrm{C}-\mathrm{H} \cdots$ centroid angle, $153^{\circ} \mathrm{]}$. The HS shows however that the main interactions are $\mathrm{OH} \cdots \mathrm{O}$ and $\mathrm{CH} \cdots \mathrm{O}$ hydrogen bonds. There are certain similarities between the structure of $\mathbf{3}$ and that of the monoperiodic, helical complex $\left[\mathrm{Ni}(\text { bipy })_{3}\right]\left[\mathrm{UO}_{2}(\mathrm{pht})\left(\mathrm{NO}_{3}\right)\right]_{2},{ }^{[10]}$ isolated as a chiral crystal in which the uranium centres, as here, have hexagonal-bipyramidal coordination and the polymer involves $\operatorname{bis}\left(\kappa^{2} O, O^{\prime}\right)$ bridging, providing the only known example of exclusive adoption of this coordination mode for phthalate on uranyl ion. In essence, for complex 3 one $\mathrm{cpa}^{2-}$ unit can be regarded as replacing the nitrate ion of the phthalate structure. While no exact analogue of $\mathbf{3}$ is known for $1,2-\mathrm{pda}^{2-}$, $\operatorname{bis}\left(\kappa^{2} \mathrm{O}, \mathrm{O}^{\prime}\right)$ coordination can be said to be typical of this ligand ${ }^{[11-13]}$ and is frequently associated with uranium in a hexagonal-bipyramidal environment, indicating that this may be a factor opposing large chelate ring formation.

The unique uranyl cation in $\left[\mathrm{UO}_{2}(\mathrm{cpa})_{2} \mathrm{Ni}\left(R, S-\mathrm{Me}_{6} \mathrm{cyclam}\right)\right](4)$ is $\kappa^{2} O, O^{\prime}$-chelated by one ligand and it is bound to three more oxygen donors from three additional $\mathrm{cpa}^{2-}$ ligands, the uranium atom environment being pentagonal-bipyramidal [U-O(oxo), 1.770(3) and

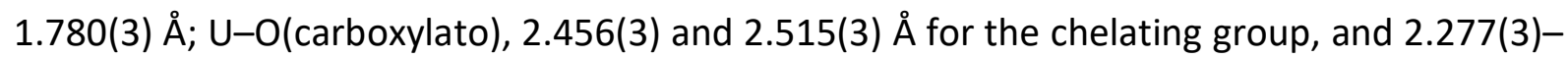
2.395(3) $\AA$ for the others] (Figure 4). Axial coordination of carboxylate oxygen atoms to both 

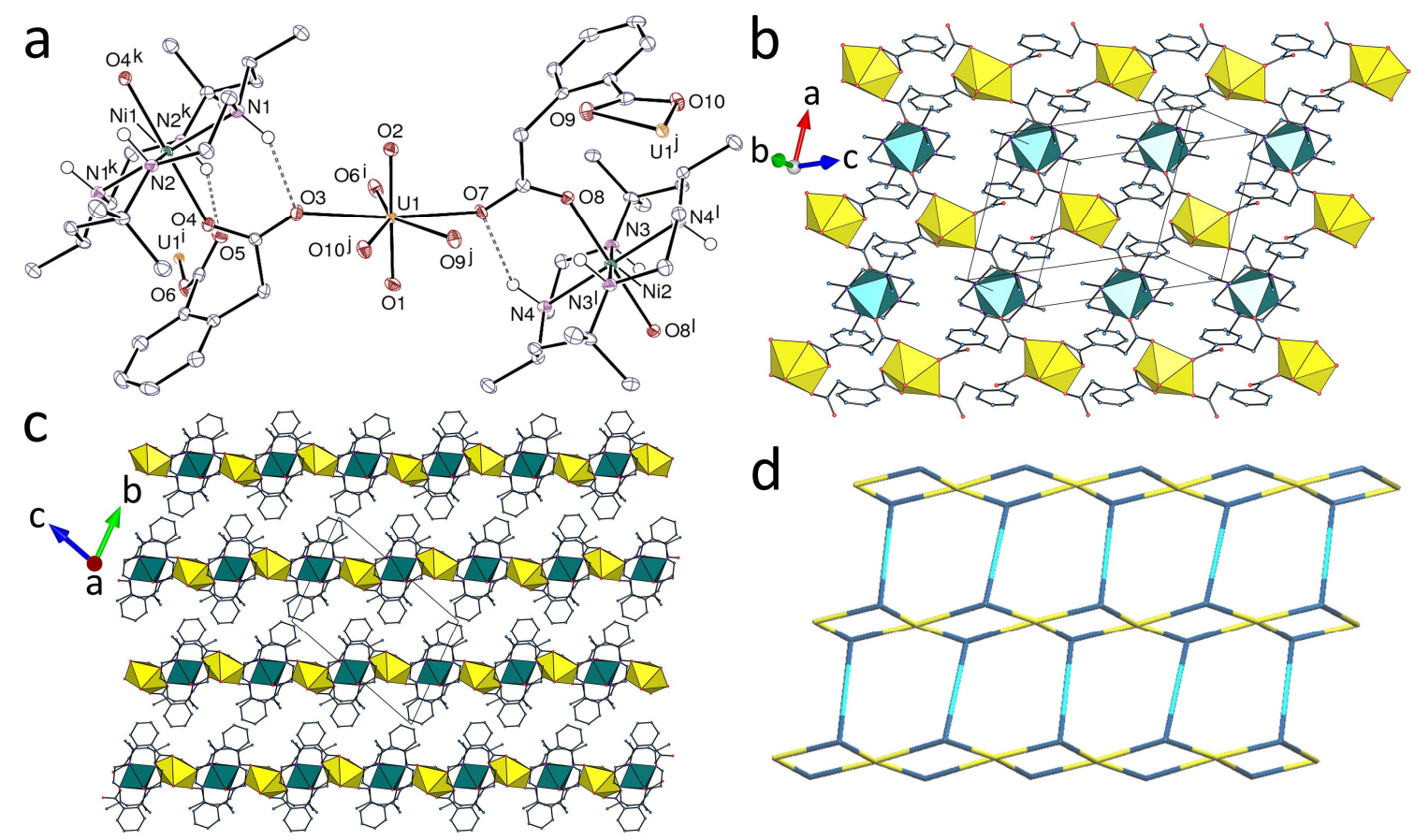

Figure 4. (a) View of complex 4 with displacement ellipsoids drawn at the $50 \%$ probability level. Carbon-bound hydrogen atoms are omitted and hydrogen bonds are shown as dashed lines. Symmetry codes: $\mathrm{i}=1-x, 1-y,-$ $z ; j=1-x,-y, 1-z ; k=2-x, 1-y,-z ; l=-x,-y, 1-z$. (b) View of the diperiodic coordination polymer with uranium coordination polyhedra yellow and those of nickel green. (c) Packing with layers viewed edge-on. (d) Nodal representation of the network (yellow, uranium nodes; dark blue, dicarboxylate nodes; light blue, nickel links; orientation slightly rotated with respect to that in (b)).

trans positions on the two centrosymmetric $\mathrm{Ni}^{l l}$ macrocycle complexes modifies the behaviour of $\mathrm{cpa}^{2-}$ in such a way that it adopts two different uranyl-bridging modes. Each of the two independent ligands has one carboxylate group bridging uranium and nickel in the syn/anti $\mu_{2}-\kappa^{1} O: \kappa^{1} O^{\prime}$ mode, but the second carboxylate group is monodentate in one ligand and chelating in the other. Ignoring the further interactions with $\mathrm{Ni}^{\prime \prime}$, these bridging modes alternate in pairs to give a monoperiodic polymer. These polymer units are linked into diperiodic sheets parallel to (011) by the coordination to the two inequivalent $\mathrm{Nil}$ sites, both located on inversion centres. Uranium atoms are 4-c nodes, $\mathrm{cpa}^{2-}$ are 3-c nodes and nickel atoms are simple links, and the network has the vertex symbol $\left\{4.6^{2}\right\}_{2}\left\{4^{2} \cdot 6^{2} .8^{2}\right\}$ and the 
topological type 3,4L13, previously found in some transition metal ion complexes, ${ }^{[26,27]}$ and also in some uranyl compounds,,$^{[9,28,29]}$ with one particular example involving $1,4-$ pda $^{2-} \cdot{ }^{[13]}$ No significant $\pi$-stacking interaction is apparent in this case, the only weak interactions worthy of note being the hydrogen bonds between the amine groups of $R, S-M e_{6}$ cyclam and

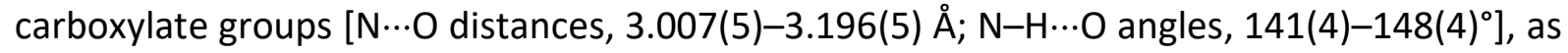
well as the usual $\mathrm{CH} \ldots \mathrm{O}$ hydrogen bonds. The network is quite planar, with the aromatic groups pointing outward on either side, and the KPI is 0.72 .

The complex $\left[\mathrm{dmaepH}_{2}\right]\left[\left(\mathrm{UO}_{2}\right)_{2}(1,2-\mathrm{pda})_{3}\right] \cdot 3 \mathrm{H}_{2} \mathrm{O}(5)$, where dmaep is the piperazine derivative generated in situ from Mestrien (see above), is shown in Figure 5. The unique
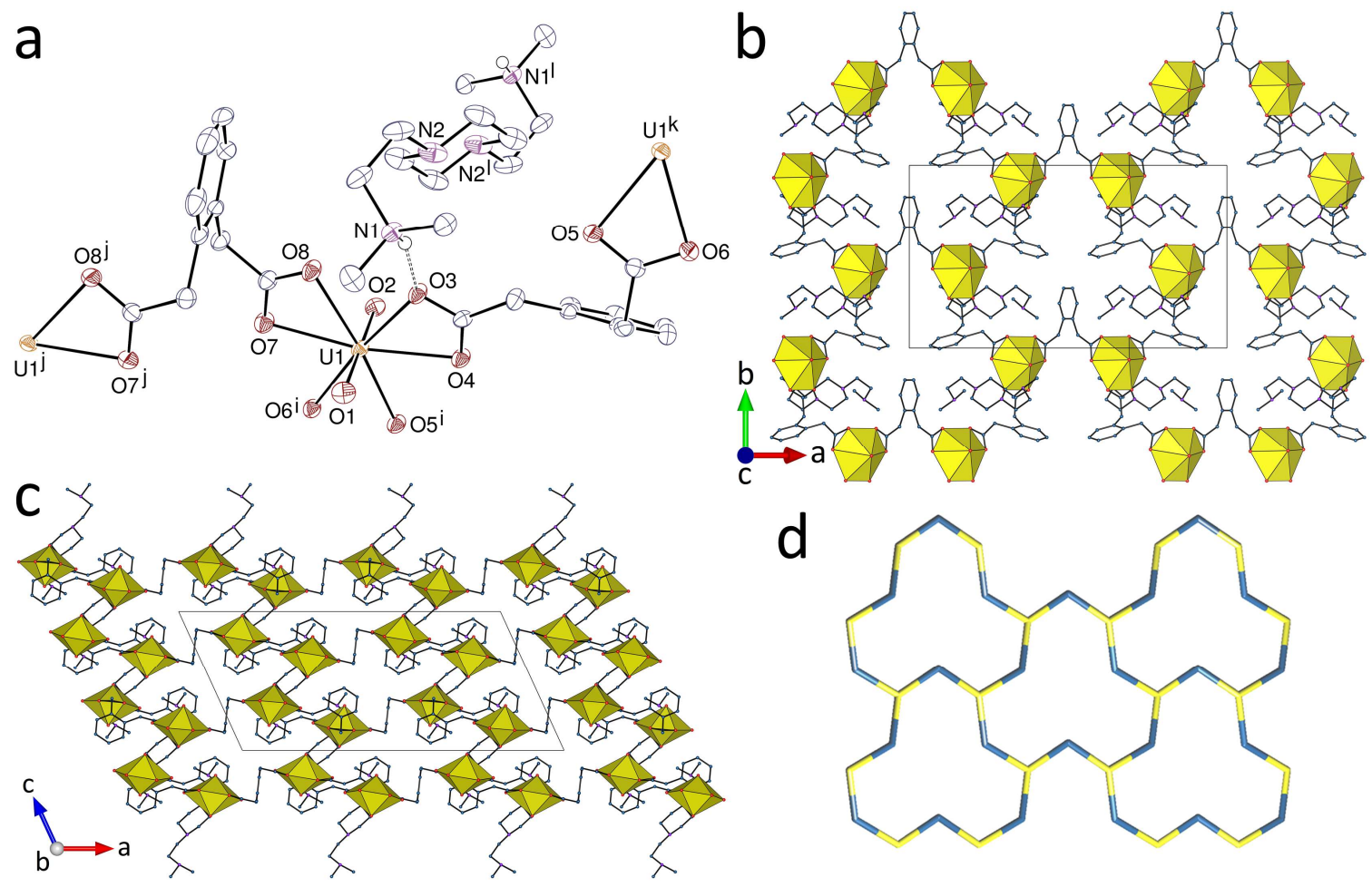

Figure 5. (a) View of complex 5 with displacement ellipsoids drawn at the $50 \%$ probability level. Solvent molecules and carbon-bound hydrogen atoms are omitted, and the hydrogen bond is shown as a dashed line. Symmetry codes: $\mathrm{i}=3 / 2-x, y+1 / 2,3 / 2-z ; \mathrm{j}=2-x, y, 3 / 2-z ; \mathrm{k}=3 / 2-x, y-1 / 2,3 / 2-z ; \mathrm{l}=3 / 2-x, 1 / 2-y, 1$ - z. (b) View of the diperiodic coordination polymer with the counterions. (c) Packing with layers viewed edgeon. (d) Nodal representation of the network (yellow, uranium nodes; dark blue, dicarboxylate links; same orientation as in (b)). 
uranyl cation is $\kappa^{2} O, O^{\prime}$-chelated by three carboxylate groups [U-O(oxo), 1.7745(15) and

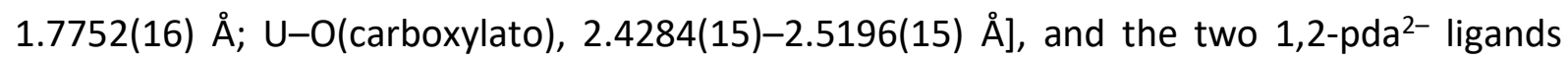
(one of them on a twofold rotation axis) are bis-chelated. The diperiodic polymer formed, parallel to (001), has the hcb topology with distorted, pseudo-trigonal cells and a step-like profile, and is essentially identical to that found in $\left[\mathrm{C}\left(\mathrm{NH}_{2}\right)_{3}\right]_{2}\left[\left(\mathrm{UO}_{2}\right)_{2}(1,2-\right.$ pda) $\left.)_{3}\right] \cdot 0.5 \mathrm{H}_{2} \mathrm{O} \cdot \mathrm{CH}_{3} \mathrm{CN} \cdot{ }^{[13]}$ The centrosymmetric, diprotonated $\mathrm{dmaepH}_{2}{ }^{2+}$ cation, where the piperazine ring has a chair conformation and the two dimethylaminoethyl groups are attached equatorially, with protons located on the terminal dimethylamino groups, is involved in fewer hydrogen bonding interactions than guanidinium, being bound to two

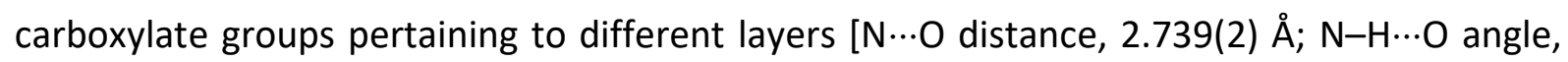
$\left.157(3)^{\circ}\right]$, and thus assembling the layers into a triperiodic assembly (KPI, 0.70). No significant parallel $\pi$-stacking interaction is apparent in this case, with no centroid...centroid distance shorter than $5.9 \AA$, but $\mathrm{CH} \cdots \pi$ interactions involving the $-\mathrm{CH}_{2}-\mathrm{CH}_{2}-$ groups of the cations may be significant $[\mathrm{H} \cdots$ centroid distances, 2.72 and $2.89 \AA$; $\mathrm{C}-\mathrm{H} \cdots$ centroid angles, 132 and $\left.129^{\circ}\right]$, and they appear on the $\mathrm{HS}$, as well as $\mathrm{CH} \cdots \mathrm{O}$ hydrogen bonds involving the terminal methyl groups of the cation and carboxylate groups.

The consequences of limiting strong hydrogen bonding of a countercation to a single site are rather strikingly revealed in the structure of $[\mathrm{QH}]_{2}\left[\left(\mathrm{UO}_{2}\right)_{2}(1,2-\mathrm{pda})_{3}\right] \cdot 3 \mathrm{CH}_{3} \mathrm{CN}$ (6) where the coordination polymer is triperiodic, the first found to be formed with the 1,2$\mathrm{pda}^{2-}$ ligand (Figure 6). The two independent uranyl cations are tris-chelated by carboxylates from three separate ligands, two of one chirality and one of the other [U-O(oxo), 1.773(3)- 

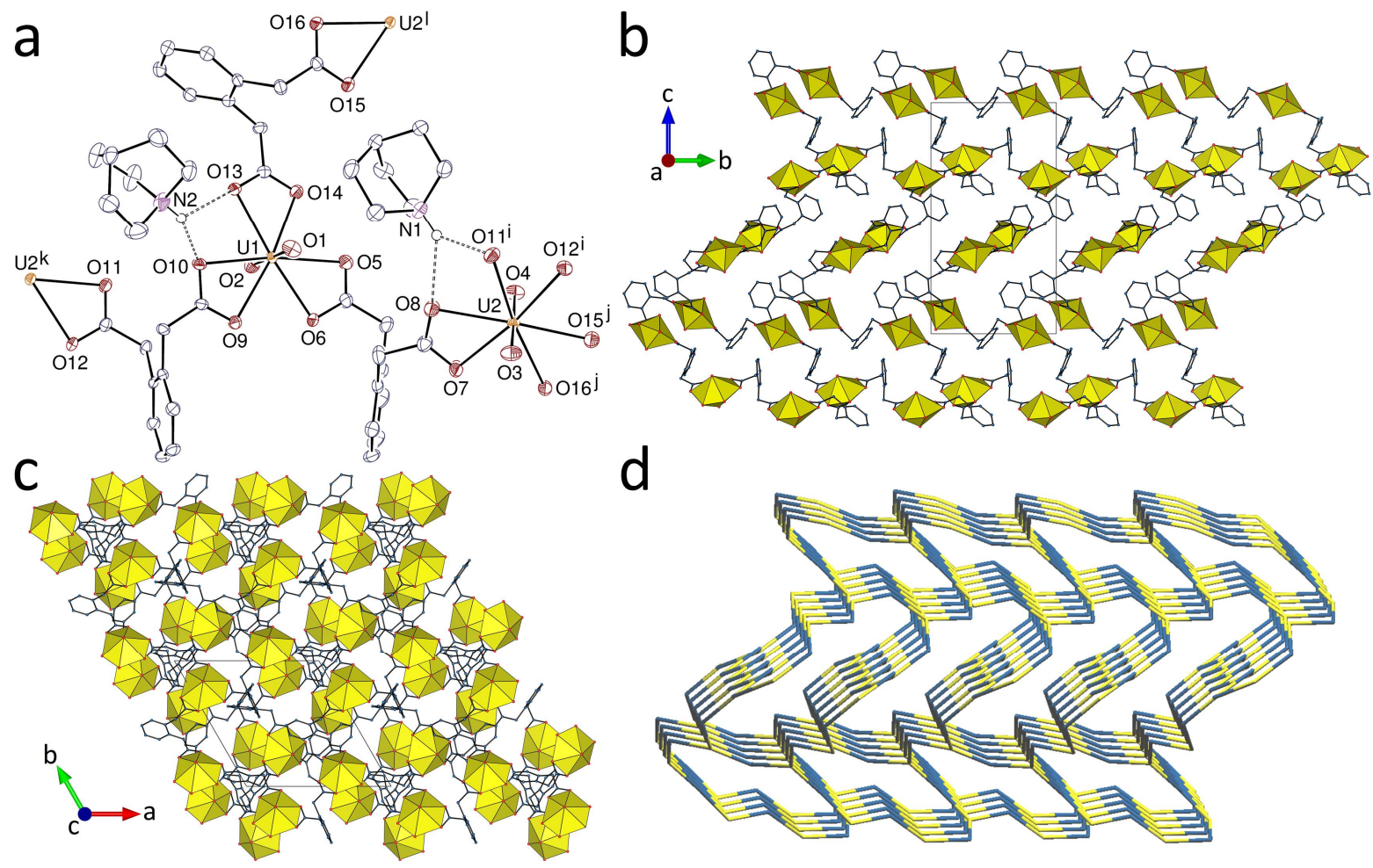

Figure 6. (a) View of complex 6 with displacement ellipsoids drawn at the $50 \%$ probability level. Solvent molecules and carbon-bound hydrogen atoms are omitted, and the hydrogen bonds are shown as dashed lines. Symmetry codes: $\mathrm{i}=1-y, x-y, z+1 / 3 ; \mathrm{j}=1-y, x-y+1, z+1 / 3 ; \mathrm{k}=y-x+1,1-x, z-1 / 3 ; \mathrm{l}=y-x, 1-x, z-$ 1/3. (b) and (c) Two views of the triperiodic framework with hydrogen atoms, counterions and solvent molecules omitted. (d) Nodal representation of the framework (yellow, uranium nodes; dark blue, dicarboxylate links; orientation slightly rotated with respect to that in (b)).

$1.776(3) \AA ; \quad \mathrm{O}-\mathrm{O}$ (carboxylato), $2.414(3)-2.510(3) \AA]$, the ligand role and pseudo- $C_{2}$ conformation being as in $\mathbf{5}$. The uninodal, 3-c framework formed has the point symbol $\left\{10^{3}\right\}$ and the topological type bto, a uninodal subnet of qtz. The $\mathrm{NH} \cdots \mathrm{O}$ interactions are bifurcated and involve two carboxylate oxygen atoms coordinated to the same uranium atom, so as to form rings with the graph set descriptor ${ }^{[30,31]} R_{1}{ }^{2}(4)[\mathrm{N} \cdots \mathrm{O}$ distances, $2.730(5)-$ 3.270(5) $\AA$; $\mathrm{N}-\mathrm{H} \cdots \mathrm{O}$ angles, $\left.127(5)-156(6)^{\circ}\right]$. In this case, there is no contribution of $\pi$ stacking or $\mathrm{CH} \cdots \pi$ interactions, but $\mathrm{CH} \cdots \mathrm{O}$ interactions are present. The triperiodic nature of the polymer is now associated with cavities in the form of flat channels running parallel to 
the (001) plane, which enclose the hydrophobic tail of the quinuclidine units and the acetonitrile molecules, the packing having no significant free space (KPI, 0.70).

The complex $[\mathrm{QH}]_{2}\left[\left(\mathrm{UO}_{2}\right)_{2}(1,4-\mathrm{pda})_{3}\right] \cdot 2 \mathrm{CH}_{3} \mathrm{CN}(7)$, shown in Figure 7 , illustrates the effect of the same quinuclidinium cation on the structure involving the related, but divergent ligand $1,4-\mathrm{pda}^{2-}$. Here also, the unique uranyl cation is chelated by three carboxylate groups [U-O(oxo), 1.7802(16) and 1.7806(16) $\AA$; U-O(carboxylato), 2.4391(16)$2.5156(16) \AA]$, but the coordination polymer formed is monoperiodic and it has the daisy-

a

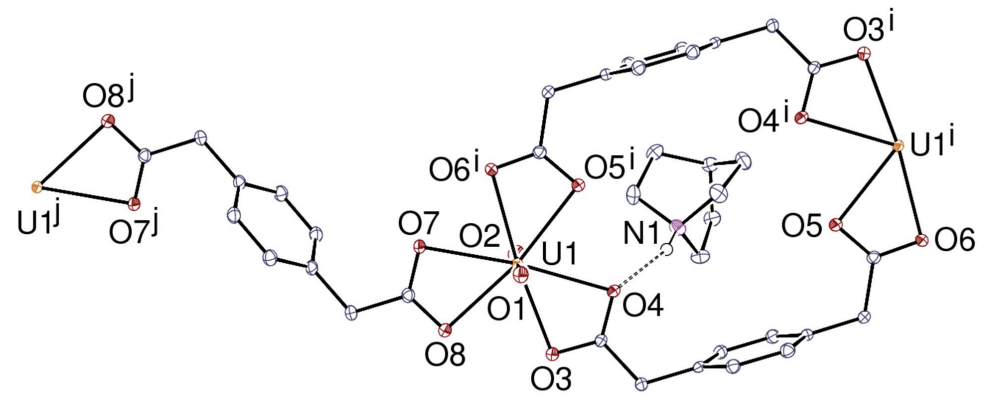

b

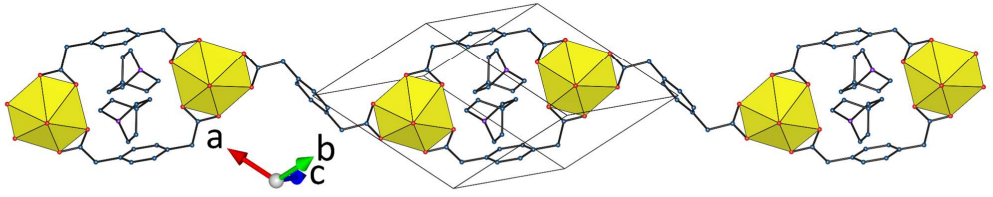

C
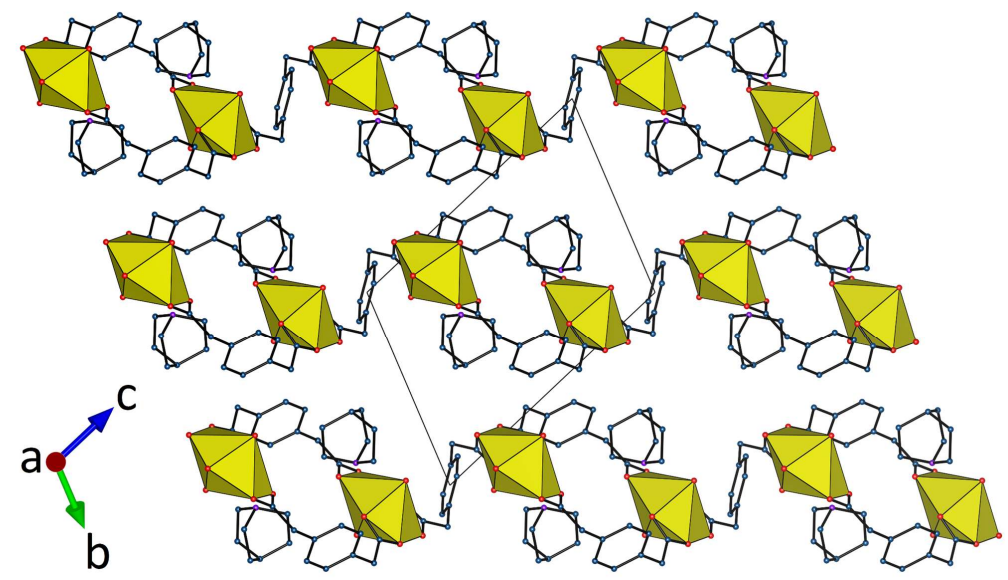

Figure 7. (a) View of complex 7 with displacement ellipsoids drawn at the $50 \%$ probability level. Solvent molecules and carbon-bound hydrogen atoms are omitted, and the hydrogen bond is shown as a dashed line. Symmetry codes: $\mathrm{i}=1-x, 1-y, 1-z ; \mathrm{j}=-x, 2-y, 2-z$. (b) View of the monoperiodic coordination polymer with the counterions. (c) Packing with chains viewed obliquely. 
chain-like shape familiar from earlier studies of 1,4-pda ${ }^{2-}$ complexes where 22-membered diuranacyclic units with the ligands in a cis configuration are linked by single ligands in a trans configuration, resulting in the formation of a quasi-linear chain (zigzag chains are formed when all ligands are cis, such as in $\left.\left[\mathrm{H}_{2} \mathrm{NMe}_{2}\right]_{2}\left[\left(\mathrm{UO}_{2}\right)_{2}(1,4-\mathrm{pda})_{3}\right]\right)^{[13]}$ and further confirming the nature of the ligand as a bis $\left(\kappa^{2} O, O^{\prime}\right)$-bridging unit. A very similar structure is found in $\left[\mathrm{PPh}_{3} \mathrm{Me}\right]\left[\mathrm{H}_{2} \mathrm{NMe}_{2}\right]\left[\left(\mathrm{UO}_{2}\right)_{2}(1,4-\mathrm{pda})_{3}\right] \cdot \mathrm{H}_{2} \mathrm{O}$, in which the dimethylammonium cation is held by two hydrogen bonds within the dinuclear ring. ${ }^{[13]}$ Here, two $\mathrm{QH}^{+}$counterions are associated with each diuranacyclic unit, and they form single hydrogen bonds with carboxylate oxygen atoms $\left[\mathrm{N} \cdots \mathrm{O}\right.$ distance, $3.034(3) \AA ; \quad \mathrm{N}-\mathrm{H} \cdots \mathrm{O}$ angle, $\left.161(3)^{\circ}\right]$. The orientation of the phenyl rings of the diuranacycles is such as to provide walls to a small cavity, into which the $\mathrm{NH}$ part of the protonated quinuclidine cations partly intrude, the packing being quite compact $(\mathrm{KPI}, 0.73)$. Adjacent chains are associated by parallel-displaced $\pi$-stacking interactions between the cis 1,4-pda ${ }^{2-}$ ligands of the dinuclear units [centroid...centroid distance, 3.5909(12) $\AA$; dihedral angle, $0^{\circ}$; slippage, $1.30 \AA ̊$ ]. Further weak bonding is provided by the aromatic ring of the trans ligand being involved in two $\mathrm{CH} \cdots \pi$ interactions with $\mathrm{QH}^{+}$cations $[\mathrm{H} \cdots$ centroid distance, $2.70 \AA$; $\mathrm{C}-\mathrm{H} \cdots$ centroid angle, $\left.175^{\circ}\right]$

Where ligand flexibility, as in the presently described species, is the result of rotation about relatively unencumbered single bonds, the barriers to conformational rearrangements appear to be of comparable energy to solid state interactions such as hydrogen bonding and aromatic $\cdots$ aromatic attractions, as well as inter-ligand repulsions within the uranyl ion equatorial coordination sites. Where no strong hydrogen bond donors are present and carboxylate oxygen atoms are the only centres available for coordination to uranium, as in complex 1, all four donor atoms of $\mathrm{cpa}^{2-}$ are used, with the ligand constrained to a 
conformation where an eight-membered chelate ring with a separation between proximal coordinated oxygen atoms of $2.872(2) \AA$ can form. If another chelate ligand such as 1,10 phenanthroline, well-known to cause congestion of the uranyl ion equatorial donor atom array, ${ }^{[24]}$ is present, as in complex $\mathbf{2}$, formation of the large chelate ring by $\mathrm{cpa}^{2-}$ does not occur and the ligand acts as a bis $\left(\kappa^{2} O, O^{\prime}\right)$ bridging species where the minimum $0 \cdots O$ separation (between the two carboxylate entities of a single ligand) is 3.831(7) $\AA$. Where the complex stoichiometry is such that six carboxylate oxygen donors are available for every uranyl ion, as in complex 3, the ligand provides this environment by acting again as a bis $\left(\kappa^{2} O, O^{\prime}\right)$ bridging species, with minimum $0 \cdots O$ separations in the three inequivalent ligand units of $3.432(3), 4.735(3)$ and $4.862(3) \AA$. In complex 4, where the U:ligand ratio is 1:2 with thus more than enough carboxylate donors for six to be bound to each uranium centre but where there is competition for them through weak axial binding to $\mathrm{Ni}$ ", the ligand acts as a $\kappa^{2} O, O^{\prime}: \kappa^{1} O^{\prime \prime}$ or $\kappa^{1} O: \kappa^{1} O^{\prime \prime}$ bridging species towards $U^{\mathrm{VI}}$, with minimum $0 \cdots O$ separations in the two inequivalent ligand units of 3.260(4) and 4.421(4) $\AA$. The substantial variation in the minimum $\mathrm{O} \cdots \mathrm{O}$ separations in these four cases is an index of the ligand flexibility, which is clearly considerable and provides a means of adapting to various other influences upon the uranium-ligand interaction.

In known complexes of 1,2-pda ${ }^{2-},{ }^{[11-13]}$ none of which involves a nine-membered chelate ring, minimum $0 \cdots 0$ separations again vary over a large range of $\sim 1.5 \AA$, very similar to that for $\mathrm{cpa}^{2-}$ if the one case there of chelation is ignored. In contrast, for known complexes of phthalate $\left(\mathrm{pht}^{2-}\right)$, minimum $\mathrm{O} \cdots \mathrm{O}$ separations, most of which apply to sevenmembered chelate rings, have a much smaller range of $<0.5 \AA$. For the three ligands pht $^{2-}$, $\mathrm{cpa}^{2-}$ and 1,2-pda ${ }^{2-}$, it appears that the introduction of but one extra single bond as in $\mathrm{pht}^{2-}$ vs $\mathrm{cpa}^{2-}$ provides sufficient flexibility to reduce markedly the probability of large chelate ring 
formation, even though such chelation does remain possible. In the formation of carbocycles, kinetic factors are responsible for favouring the formation of five- and sixmembered rings but with a labile metal ion such as uranyl the thermodynamic difference between chelating and bridging modes must be determinant. Here, however, there is a complication in that with dicarboxylates a large chelate ring involves only one oxygen atom of each carboxylate while bridging can involve four in a bis $\left(\kappa^{2} O, O^{\prime}\right)$ form. In fact, in all known uranyl ion complexes of pht $^{2-}$ in the solid state, at least 3 and commonly all 4 oxygen atoms are involved in coordination to uranium as a result of interactions in addition to (and in some cases, in place of) seven-membered chelate ring formation, so that no direct comparison of the one instance of bis $\left(\kappa^{2} O, O^{\prime}\right)$ bridging with any species in which there is exclusively seven-membered ring chelation is possible. Similarly, where $\mathrm{cpa}^{2-}$ forms an eightmembered chelate ring (complex 1), additional interactions result in all 4 oxygen donors being coordinated to uranium, so again no simple comparisons with species such as complexes $\mathbf{2}$ and $\mathbf{3}$ where bis $\left(\kappa^{2} O, O^{\prime}\right)$ bridging alone occurs can be made.

The obvious reasons for this frustrating situation are that the stoichiometry and composition of the known complexes vary greatly. Where at least the stoichiometry is such as to give a carboxylate:uranium ratio of 3:1, the ligands $\mathrm{cpa}^{2-}$ and 1,2-pda ${ }^{2-}$ (as well as 1,3and 1,4-pda ${ }^{2-}$, the latter exemplified in complex 7) act as bis $\left(\kappa^{2} O, O^{\prime}\right)$ bridging units and give the uranyl ion hexagonal-bipyramidal coordination geometry, possibly implying that this is a favoured situation. Unfortunately, no structurally characterized uranyl phthalate complex has this stoichiometry, even when resulting from a reaction mixture with the appropriate composition. Thus, it appears that solid state interactions in addition to those of coordinate bond formation which simply determine the solubility of a given species are the determinants of a given coordination mode observed within a crystal. Note that in phthalate 
complexes where only 3 of the 4 oxygen donor atoms are coordinated to uranium, the fourth donor is involved in $\mathrm{O} \cdots \mathrm{HO}, \mathrm{O} \cdots \mathrm{HN}, \mathrm{O} \cdots \mathrm{HC}$ or $\mathrm{O} \cdots$ (heterometal) interactions, indicating that these may be competitive in energy with weak coordination to $\mathrm{U}^{\mathrm{V}}$.

From a topological viewpoint, it is notable that $\mathrm{cpa}^{2-}$, as $1,4-\mathrm{pda}^{2-}{ }^{-[12]}$ has a propensity to give monoperiodic coordination polymers with the uranyl ion, and diperiodic networks have only been obtained in the presence of a metal-containing, bulky counterion, either separated (3) or included in the polymeric assembly (4). Ligand flexibility may be important in the case of complex $\mathbf{3}$ in enabling significant distortions of the hcb topology of the diperiodic uranyl-cpa ${ }^{2-}$ polymer to occur in such a way as to optimize interactions with the countercation. Surprisingly, the use of an organic countercation of moderate size and limited in its hydrogen bonding capabilities, quinuclidinium, allowed isolation of the first triperiodic framework in the uranyl phenylenediacetate family (6).

\section{Conclusions}

One of the difficulties involved in assessing the influence of increased flexibility of a ligand molecule when this flexibility enhancement results from insertion of additional single bonds, is that chelation may simply become not just improbable but actually impossible. This, however, is not the case with the presently considered ligands. Thus, $\mathrm{pht}^{2-}$ and $\mathrm{cpa}^{2-}$ are known to form complexes involving seven-and eight-membered chelate rings, respectively, and while $1,2-\mathrm{pda}^{2-}$ is not yet known to form complexes involving nine-membered chelate rings, it is pertinent to note that for the conformationally restricted $1,1^{\prime}$-biphenyl-2, $2^{\prime}, 6,6^{\prime}$ tetracarboxylate, nine-membered ring chelation is common ${ }^{[32,33]}$ and it is also seen in complexes of $2,2^{\prime}$-bipyridine-3,3'-dicarboxylate. ${ }^{[34-36]}$ If an increase in rotational flexibility results in a higher population of conformations incompatible with chelation, the probability 
of finding species involving chelation must be reduced and this would certainly explain the current observations on uranyl ion complexes of $\mathrm{pht}^{2-}, \mathrm{cpa}^{2-}$ and 1,2-pda ${ }^{2-}$. There is, however, an extra matter to consider relating to the coordination sphere of uranyl ion. As is evident from a variety of facts such as pentagonal-bipyramidal coordination in adducts of $\mathrm{UO}_{2}(\mathrm{acac})_{2}{ }^{[37]}$ major distortions of the coordination geometry by ligands such as 1,10 phenanthroline, ${ }^{[38]}$ and the limitation of hexagonal-bipyramidal coordination to species involving at least partly small-bite ligands such as nitrate and carboxylate, ${ }^{[10]}$ coordination in the equatorial plane of uranyl ion is sensitive to inter-ligand repulsions. This is further seen in that species where two nine-membered chelate rings are present ${ }^{[32-36]}$ have uranium in octahedral (square-bipyramidal) coordination, any addition to the four donor atoms in the equatorial plane apparently being excluded. As U-(equatorial donor atom) bond lengths shorten with decrease in coordination number, implying that the individual bonds are stronger, this means that all systems must reflect different balance points between the number and strength of coordinative interactions. In cases, such as the present, where chelate ring sizes differ, this need not have anything to do with ligand flexibility other than as a means of adjusting the distance spanned by the ligand. Were it to be assumed that the most favourable interaction of carboxylate ligands with uranium(VI) would be that of hexagonal-bipyramidal, $\operatorname{tris}\left(\kappa^{2} O, O^{\prime}\right)$ coordination, then the increasing frequency of this mode in passing from $\mathrm{pht}^{2-}$ through $\mathrm{cpa}^{2-}$ to $1,2-\mathrm{pda}^{2-}$ can be seen as an effect of stepwise increase in flexibility.

\section{Experimental Section}

General: $\left[\mathrm{UO}_{2}\left(\mathrm{NO}_{3}\right)_{2}\left(\mathrm{H}_{2} \mathrm{O}\right)_{2}\right] \cdot 4 \mathrm{H}_{2} \mathrm{O}$ (RP Normapur, 99\%) was purchased from Prolabo. 2carboxyphenylacetate was from EGA, and 1,2- and 1,4-phenylenediacetates were from 
Aldrich. [Ni(R,S-Me 6 Cyclam $\left.)\left(\mathrm{NO}_{3}\right)_{2}\right]$ was synthesized as previously described. ${ }^{[39]}$ When possible, elemental analyses were performed by Service Chromato-Masse Microanalyse (UMR 8076) of Université Paris-Saclay. For complexes 2 and 5-7, the low yield prevented further characterization. For all syntheses, the mixtures in demineralized water were placed in $10 \mathrm{~mL}$ tightly closed glass vessels and heated at $140{ }^{\circ} \mathrm{C}$ in a sand bath, under autogenous pressure.

Caution! Uranium is a radioactive and chemically toxic element, and uranium-containing samples must be handled with suitable care and protection. Small quantities of reagents and solvents were employed to minimize any potential hazards arising both from the presence of uranium and the use of pressurized vessels for the syntheses.

[UO 2 (cpa)] (1): $\mathrm{cpaH}_{2}(18 \mathrm{mg}, 0.10 \mathrm{mmol})$ and $\left[\mathrm{UO}_{2}\left(\mathrm{NO}_{3}\right)_{2}\left(\mathrm{H}_{2} \mathrm{O}\right)_{2}\right] \cdot 4 \mathrm{H}_{2} \mathrm{O}(50 \mathrm{mg}, 0.10 \mathrm{mmol})$ were dissolved in a mixture of water $(0.7 \mathrm{~mL})$ and acetonitrile $(0.2 \mathrm{~mL})$, giving yellow crystals of complex 1 overnight (8 mg, 18\% yield). $\mathrm{C}_{9} \mathrm{H}_{6} \mathrm{O}_{6} \mathrm{U}$ (448.17): calcd. C 24.12, H 1.35; found C 24.06, H 1.44.

[UO ${ }_{2}$ (cpa)(phen)] (2): $\mathrm{cpaH}_{2}(18 \mathrm{mg}, 0.10 \mathrm{mmol}),\left[\mathrm{UO}_{2}\left(\mathrm{NO}_{3}\right)_{2}\left(\mathrm{H}_{2} \mathrm{O}\right)_{2}\right] \cdot 4 \mathrm{H}_{2} \mathrm{O}(35 \mathrm{mg}, 0.07$ $\mathrm{mmol}$ ), $\mathrm{Pb}\left(\mathrm{NO}_{3}\right)_{2}(33 \mathrm{mg}, 0.10 \mathrm{mmol})$, and 1,10-phenanthroline $(18 \mathrm{mg}, 0.10 \mathrm{mmol}$ ) were dissolved in a mixture of water $(0.8 \mathrm{~mL})$ and THF $(0.2 \mathrm{~mL})$, giving a few yellow crystals of complex 2 overnight.

[Ni(bipy) $\left.)_{3}\right]\left[\left(\mathrm{UO}_{2}\right)_{2}(\mathrm{cpa})_{3}\right] \cdot 2.5 \mathrm{H}_{2} \mathrm{O}$ (3): $\mathrm{cpaH}_{2}(18 \mathrm{mg}, 0.10 \mathrm{mmol}),\left[\mathrm{UO}_{2}\left(\mathrm{NO}_{3}\right)_{2}\left(\mathrm{H}_{2} \mathrm{O}\right)_{2}\right] \cdot 4 \mathrm{H}_{2} \mathrm{O}(35$ $\mathrm{mg}, 0.07 \mathrm{mmol}$ ), $\mathrm{Ni}\left(\mathrm{NO}_{3}\right)_{2} \cdot 6 \mathrm{H}_{2} \mathrm{O}$ (15 mg, $0.05 \mathrm{mmol}$ ), and 2,2'-bipyridine (24 mg, $0.15 \mathrm{mmol}$ ) 
were dissolved in a mixture of water $(0.6 \mathrm{~mL})$ and $\mathrm{DMF}(0.2 \mathrm{~mL})$, giving orange crystals of complex 3 within one week ( $27 \mathrm{mg}, 49 \%$ yield based on the acid). $\mathrm{C}_{57} \mathrm{H}_{47} \mathrm{~N}_{6} \mathrm{NiO}_{18.5} \mathrm{U}_{2}$ (1646.77): calcd. C 41.57, H 2.88, N 5.10; found C 41.51, H 2.82, N 5.19.

[UO $\left.{ }_{2}(\mathrm{cpa})_{2} \mathrm{Ni}\left(\boldsymbol{R}, \mathrm{S}-\mathrm{Me}_{6} \mathrm{cyclam}\right)\right]$ (4): $\mathrm{cpaH}_{2}(18 \mathrm{mg}, 0.10 \mathrm{mmol}),\left[\mathrm{UO}_{2}\left(\mathrm{NO}_{3}\right)_{2}\left(\mathrm{H}_{2} \mathrm{O}\right)_{2}\right] \cdot 4 \mathrm{H}_{2} \mathrm{O}(35$ $\mathrm{mg}, 0.07 \mathrm{mmol})$, and $\left[\mathrm{Ni}\left(R, \mathrm{~S}-\mathrm{Me}_{6} \mathrm{Cyclam}\right)\left(\mathrm{NO}_{3}\right)_{2}\right](23 \mathrm{mg}, 0.05 \mathrm{mmol})$ were dissolved in a mixture of water $(0.6 \mathrm{~mL})$ and DMF $(0.2 \mathrm{~mL})$, giving yellow crystals of complex 4 overnight (21 mg, 31\% yield based on U). $\mathrm{C}_{34} \mathrm{H}_{48} \mathrm{~N}_{4} \mathrm{NiO}_{10} \mathrm{U}$ (969.5): calcd. C 42.12, H 4.99, N 5.78; found C 42.14, H 4.79, N 5.89 .

[dmaepH $\left.\mathrm{d}_{2}\right]\left[\left(\mathrm{UO}_{2}\right)_{\mathbf{2}}(\mathbf{1}, \mathbf{2}-\mathrm{pda})_{3}\right] \cdot 3 \mathrm{H}_{\mathbf{2}} \mathrm{O}$ (5): 1,2-pdaH $2(20 \mathrm{mg}, 0.10 \mathrm{mmol}), \mathrm{UO}_{2}\left(\mathrm{NO}_{3}\right)_{2} \cdot 6 \mathrm{H}_{2} \mathrm{O}(35$ $\mathrm{mg}, 0.07 \mathrm{mmol})$, and $\left(\mathrm{Me}_{6}\right.$ trien) $\left(\mathrm{HCF}_{3} \mathrm{SO}_{3}\right)_{4}(30 \mathrm{mg}, 0.04 \mathrm{mmol})$ were dissolved in a mixture of water $(0.8 \mathrm{~mL})$ and DMF $(0.2 \mathrm{~mL})$, giving a few yellow crystals of complex 5 within one week.

$[\mathrm{QH}]_{2}\left[\left(\mathrm{UO}_{2}\right)_{2}(1,2-\mathrm{pda})_{3}\right] \cdot 3 \mathrm{CH}_{3} \mathrm{CN}(6): 1,2-\mathrm{pdaH}_{2}(20 \mathrm{mg}, 0.10 \mathrm{mmol}), \mathrm{UO}_{2}\left(\mathrm{NO}_{3}\right)_{2} \cdot 6 \mathrm{H}_{2} \mathrm{O}(35 \mathrm{mg}$, $0.07 \mathrm{mmol})$, and $\mathrm{QHCl}(15 \mathrm{mg}, 0.10 \mathrm{mmol})$ were dissolved in a mixture of water $(0.7 \mathrm{~mL})$ and acetonitrile $(0.2 \mathrm{~mL})$, giving a few yellow crystals of complex 6 within three weeks.

$\left.[\mathrm{QH}]_{2}\left[\left(\mathrm{UO}_{2}\right)_{2} \text { (1,4-pda) }\right)_{3}\right] \cdot 2 \mathrm{CH}_{3} \mathrm{CN}$ (7): 1,4-pdaH $(20 \mathrm{mg}, 0.10 \mathrm{mmol}), \mathrm{UO}_{2}\left(\mathrm{NO}_{3}\right)_{2} \cdot 6 \mathrm{H}_{2} \mathrm{O}(35 \mathrm{mg}$, $0.07 \mathrm{mmol})$, and $\mathrm{QHCl}(30 \mathrm{mg}, 0.20 \mathrm{mmol})$ were dissolved in a mixture of water $(0.7 \mathrm{~mL})$ and acetonitrile $(0.2 \mathrm{~mL})$, giving a few yellow crystals of complex 7 within one week. 
Crystallography: The data were collected at 100(2) K on a Bruker D8 Quest diffractometer equipped with an Incoatec Microfocus Source (I $\mu$ S 3.0 Mo) and a PHOTON III area detector, and operated through the APEX3 software. ${ }^{[40]}$ The crystals were mounted on Mitegen micromounts with a protective coating of Paratone- $\mathrm{N}$ oil (Hampton Research). The data were processed with SAINT, ${ }^{[41]}$ and absorption effects were corrected for empirically with SADABS. ${ }^{[42]}$ The structures were solved by intrinsic phasing with SHELXT, ${ }^{[43]}$ expanded by subsequent difference Fourier synthesis and refined by full-matrix least-squares on $F^{2}$ with SHELXL, ${ }^{[44]}$ using the ShelXle interface. ${ }^{[45]}$ All non-hydrogen atoms were refined with anisotropic displacement parameters. When present, the hydrogen atoms bound to oxygen and nitrogen atoms were found on difference Fourier maps in most cases, and they were either fully refined isotropically with restraints, or refined with an isotropic displacement parameter equal to 1.2 or 1.5 (for water) times that of the attached atom. In complexes $\mathbf{3}$ and 5, one water molecule has been given an occupancy factor of 0.5 in order to retain an acceptable displacement parameter and another one in $\mathbf{3}$ is disordered over two positions (and its hydrogen atoms were not found). The carbon-bound hydrogen atoms were introduced at calculated positions and were treated as riding atoms with an isotropic displacement parameter equal to 1.2 times that of the parent atom (1.5 for $\mathrm{CH}_{3}$, with optimized geometry). The Flack parameter for complex 2 was $0.422(11)$ (inversion twin), and that for complex 6 was $0.021(4)$. Crystal data and structure refinement parameters are given in Table 1. The molecular plots were drawn with ORTEP-3 ${ }^{[46]}$ and the polyhedral representations with VESTA. ${ }^{[47]}$ Topological analyses were conducted with ToposPro. ${ }^{[48]}$ CCDC 2065099 (for 1), 2065100 (for 2), 2065101 (for 3), 2065102 (for 4), 2065103 (for 5), 2065104 (for 6), and 2065105 (for 7) contain the supplementary crystallographic data for 
this paper. These data can be obtained free of charge from The Cambridge Crystallographic

Data Centre via www.ccdc.cam.ac.uk/data request/cif.

Table 1. Crystal data and structure refinement details.

\begin{tabular}{|c|c|c|c|c|c|c|c|}
\hline & 1 & 2 & 3 & 4 & 5 & 6 & 7 \\
\hline Empirical formula & $\mathrm{C}_{9} \mathrm{H}_{6} \mathrm{O}_{6} \mathrm{U}$ & $\mathrm{C}_{21} \mathrm{H}_{14} \mathrm{~N}_{2} \mathrm{O}_{6} \mathrm{U}$ & $\mathrm{C}_{57} \mathrm{H}_{47} \mathrm{~N}_{6} \mathrm{NiO}_{18.5} \mathrm{U}_{2}$ & $\mathrm{C}_{34} \mathrm{H}_{48} \mathrm{~N}_{4} \mathrm{NiO}_{10} \mathrm{U}$ & $\mathrm{C}_{42} \mathrm{H}_{60} \mathrm{~N}_{4} \mathrm{O}_{19} \mathrm{U}_{2}$ & $\mathrm{C}_{50} \mathrm{H}_{61} \mathrm{~N}_{5} \mathrm{O}_{16} \mathrm{U}_{2}$ & $\mathrm{C}_{48} \mathrm{H}_{58} \mathrm{~N}_{4} \mathrm{O}_{16} \mathrm{U}_{2}$ \\
\hline$M\left(\mathrm{~g} \mathrm{~mol}^{-1}\right)$ & 448.17 & 628.37 & 1646.77 & 969.50 & 1401.00 & 1464.09 & 1423.04 \\
\hline Crystal system & triclinic & orthorhombic & monoclinic & triclinic & monoclinic & trigonal & triclinic \\
\hline Space group & $P_{\overline{\mathrm{I}}}$ & $P 2_{1} 2_{1} 2_{1}$ & $P 2_{1} / n$ & $P_{\overline{\mathrm{I}}}$ & $C 2 / c$ & $P 3_{1}$ & $P_{\bar{I}}$ \\
\hline$a(\AA)$ & $5.8032(2)$ & $7.1514(3)$ & $12.2376(4)$ & $10.2024(6)$ & $27.8579(11)$ & $14.1572(5)$ & $10.2002(4)$ \\
\hline$b(\AA)$ & $8.1714(3)$ & $15.5927(8)$ & $32.4606(10)$ & $11.3579(7)$ & $14.6046(5)$ & $14.1572(5)$ & $10.7472(4)$ \\
\hline$c(\AA ̊)$ & $10.7204(4)$ & $16.3607(9)$ & $14.2062(4)$ & $16.4720(10)$ & $13.2707(5)$ & $22.6156(9)$ & $13.1019(5)$ \\
\hline$\alpha\left({ }^{\circ}\right)$ & $95.3644(16)$ & 90 & 90 & $73.035(3)$ & 90 & 90 & $103.2498(18)$ \\
\hline$\beta\left(\left(^{\circ}\right)\right.$ & $98.4453(16)$ & 90 & $97.5541(14)$ & $72.944(3)$ & $114.558(2)$ & 90 & $99.8555(19)$ \\
\hline$\gamma\left({ }^{\circ}\right)$ & $102.6684(15)$ & 90 & 90 & $86.054(3)$ & 90 & 120 & $116.2206(17)$ \\
\hline$V\left(\AA^{3}\right)$ & $486.43(3)$ & $1824.38(16)$ & $5594.3(3)$ & $1745.09(19)$ & $4910.8(3)$ & $3925.5(4)$ & $1191.59(8)$ \\
\hline$z$ & 2 & 4 & 4 & 2 & 4 & 3 & 1 \\
\hline Reflections collected & 49591 & 47578 & 201948 & 110417 & 122640 & 254395 & 195051 \\
\hline Independent reflections & 2941 & 3455 & 10616 & 6617 & 7507 & 15959 & 7293 \\
\hline Observed reflections $[I>2 \sigma(I)]$ & 2896 & 3392 & 9775 & 6241 & 6729 & 15380 & 6981 \\
\hline$R_{\text {int }}$ & 0.047 & 0.059 & 0.040 & 0.079 & 0.047 & 0.065 & 0.053 \\
\hline Parameters refined & 145 & 272 & 788 & 472 & 319 & 670 & 321 \\
\hline$R_{1}$ & 0.012 & 0.021 & 0.018 & 0.029 & 0.018 & 0.020 & 0.017 \\
\hline $\mathrm{w} R_{2}$ & 0.027 & 0.052 & 0.036 & 0.075 & 0.039 & 0.043 & 0.047 \\
\hline$S$ & 1.082 & 1.054 & 1.068 & 1.065 & 1.078 & 1.046 & 1.043 \\
\hline$\Delta \rho_{\min }\left(\mathrm{e} \AA^{-3}\right)$ & -0.66 & -1.09 & -0.73 & -1.63 & -1.07 & -0.62 & -0.71 \\
\hline$\Delta \rho_{\max }\left(\mathrm{e} \AA^{-3}\right)$ & 1.07 & 2.41 & 1.20 & 2.28 & 1.42 & 1.25 & 3.60 \\
\hline
\end{tabular}

\section{Acknowledgment}

We thank Dr. Davide Audisio for his help with interpretation of Me 6 trien transformation.

\section{References}

[1] K. X. Wang, J. S. Chen, Acc. Chem. Res. 2011, 44, 531-540.

[2] M. B. Andrews, C. L. Cahill, Chem. Rev. 2013, 113, 1121-1136.

[3] T. Loiseau, I. Mihalcea, N. Henry, C. Volkringer, Coord. Chem. Rev. 2014, 266-267, 69109.

[4] J. Su, J. S. Chen, Struct. Bond. 2015, 163, 265-296.

[5] P. Thuéry, J. Harrowfield, Dalton Trans. 2017, 46, 13660-13667.

[6] P. Thuéry, E. Rivière, J. Harrowfield, Inorg. Chem. 2015, 54, 2838-2850. 
[7] P. Thuéry, J. Harrowfield, CrystEngComm 2015, 17, 4006-4018.

[8] P. Thuéry, Y. Atoini, J. Harrowfield, Inorg. Chem. 2018, 57, 7932-7939.

[9] P. Thuéry, Y. Atoini, J. Harrowfield, Eur. J. Inorg. Chem. 2019, 4440-4449.

[10] P. Thuéry, J. Harrowfield, Cryst. Growth. Des., submitted.

[11] P. Thuéry, Y. Atoini, J. Harrowfield, Inorg. Chem. 2019, 58, 6550-6564.

[12] P. Thuéry, Y. Atoini, J. Harrowfield, Cryst. Growth Des. 2019, 19, 6611-6626.

[13] P. Thuéry, Y. Atoini, J. Harrowfield, Inorg Chem. 2020, 59, 2503-2518.

[14] C. R. Groom, I. J. Bruno, M. P. Lightfoot, S. C. Ward, Acta Crystallogr., Sect. B 2016, $72,171-179$.

[15] R. B. Wilson, R. M. Laine, J. Am. Chem. Soc. 1985, 107, 361-369.

[16] S. J. Formosinho, H. D. Burrows, M. da G. Miguel, M. E. D. G. Azenha, I. M. Saraiva, A. C. D. N. Ribeiro, I. V. Khudyakov, R. G. Gasanov, M. Bolte, M. Sarakha, Photochem. Photobiol. Sci. 2003, 2, 569-575.

[17] X. Gao, C. Wang, Z. F. Shi, J. Song, F. Y. Bai, J. X. Wang, Y. H. Xing, Dalton Trans. 2015, $44,11562-11571$.

[18] I. Mihalcea, N. Henry, T. Loiseau, Cryst. Growth Des. 2011, 11, 1940-1947.

[19] A. L. Spek, Acta Crystallogr., Sect. D 2009, 65, 148-155.

[20] M. A. Spackman, D. Jayatilaka, CrystEngComm 2009, 11, 19-32.

[21] S. K. Wolff, D. J. Grimwood, J. J. McKinnon, M. J. Turner, D. Jayatilaka, M. A. Spackman, CrystalExplorer; University of Western Australia: Crawley, Australia, 2012.

[22] R. Taylor, O. Kennard, J. Am. Chem. Soc. 1982, 104, 5063-5070.

[23] G. R. Desiraju, Acc. Chem. Res. 1996, 29, 441-449.

[24] P. Thuéry, J. Harrowfield, CrystEngComm. 2016, 18, 3905-3918.

[25] A. V. Savchenkov, M. S. Grigoriev, P. A. Udivankin, D. V. Pushkin, L. B. Serezhkina, 
Polyhedron 2017, 127, 331-336.

[26] L. Carlucci, G. Ciani, D. M. Proserpio, T. G. Mitina, V. A. Blatov, Chem. Rev. 2014, 114, 7557-7580.

[27] K. D. Demadis, Z. Anagnostou, A. Panera, G. Mezei, M. V. Kirillova, A. M. Kirillov, RSC Adv. 2017, 7, 17788-17799.

[28] P. Thuéry, J. Harrowfield, Inorg. Chem. 2015, 54, 8093-8102.

[29] P. Thuéry, Y. Atoini, J. Harrowfield, Inorg. Chem. 2020, 59, 2923-2936.

[30] M. C. Etter, J. C. MacDonald, J. Bernstein, Acta Crystallogr., Sect. B 1990, 46, 256262.

[31] J. Bernstein, R. E. Davis, L. Shimoni, N. L. Chang, Angew. Chem. Int. Ed. 1995, 34, 1555-1573.

[32] P. Thuéry, J. Harrowfield, Inorg. Chem. 2015, 54, 6296-6305.

[33] J. F. Qian, W. J. Tian, S. Yang, Z. H. Sun, L. Chen, M. J. Wei, Z. Wu, M. Y. He, Z. H. Zhang, L. Mei, Inorg. Chem. 2020, 59, 17659-17670.

[34] P. Thuéry, B. Masci, CrystEngComm 2012, 14, 131-137.

[35] G. E. Gomez, J. A. Ridenour, N. M. Byrne, A. P. Shevchenko, C. L. Cahill, Inorg. Chem. 2019, 58, 7247-7254.

[36] Y. Atoini, J. Harrowfield, Y. Kim, P. Thuéry, J. Incl. Phenom. Macrocyclic Chem. 2021, in the press, DOI: 10.1007/s10847-021-01048-8.

[37] T. Kawasaki, T. Nishimura, T. Kitazawa, T. Bull. Chem. Soc. Jpn 2010, 83, 1528-1530.

[38] J. C. Berthet, M. Nierlich, M. Ephritikhine, Chem. Commun. 2003, 1660-1661.

[39] P. Thuéry, J. Harrowfield, Cryst. Growth Des. 2018, 18, 5512-5520.

[40] Bruker AXS. APEX3. Version 2019.1-0. Madison, Wisconsin, USA, 2019.

[41] Bruker Nano, Inc. SAINT. Version 8.40A. Madison, Wisconsin, USA, 2019. 
[42] a) Bruker AXS. SADABS. Version 2016/2. Madison, Wisconsin, USA, 2016; b) L. Krause, R. Herbst-Irmer, G. M. Sheldrick, D. Stalke, J. Appl. Crystallogr. 2015, 48, 3-10.

[43] G. M. Sheldrick, Acta Crystallogr., Sect. A 2015, 71, 3-8.

[44] G. M. Sheldrick, Acta Crystallogr., Sect. C 2015, 71, 3-8.

[45] C. B. Hübschle, G. M. Sheldrick, B. Dittrich, J. Appl. Crystallogr. 2011, 44, 1281-1284.

[46] L. J. Farrugia, J. Appl. Crystallogr. 2012, 45, 849-854.

[47] K. Momma, F. Izumi, J. Appl. Crystallogr. 2011, 44, 1272-1276.

[48] V. A. Blatov, A. P. Shevchenko, D. M. Proserpio, Cryst. Growth Des. 2014, 14, 35763586. 
Table of Contents Entry

Stepwise Introduction of Flexibility into Aromatic Dicarboxylates Forming Uranyl Ion Coordination Polymers: a Comparison of

2-Carboxyphenylacetate and 1,2-Phenylenediacetate

Pierre Thuéry, Jack Harrowfield

Key Topic: Uranyl complexes

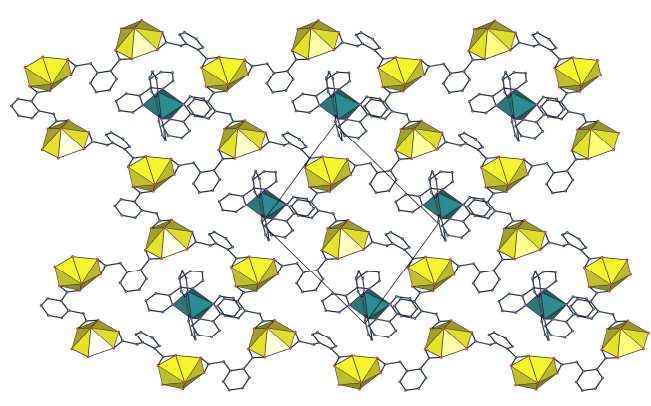

While 2-carboxyphenylacetate gives mono-or diperiodic coordination polymers with the uranyl cation, depending on the additional ligands and counterions present, 1,2phenylenediacetate yields the first triperiodic framework in the uranyl-phenylenediacetate family, in the presence of quinuclidinium cations. The results are discussed in terms of ligand flexibility and ability to form large chelate rings. 